\title{
FAKTOR RISIKO KEJADIAN DIARE PADA BALITA
}

\author{
Sugiarto, Subakir, Pitriyani \\ Program Studi Kesehatan Masyarakat, Sekolah Tinggi Ilmu Kesehatan Harapan Ibu Jambi \\ Email : mas sugik32@yahoo.com
}

\section{Track Record Article \\ Diterima: 15 Mei 2019} Dipublikasi: 25 Juni 2019

\section{Abstract}

Problems with diarrhea are still a relatively large problem. In 2017 the number of diarrhea among toddlers in Indonesia was 40.07\% and there were 21 times diarrhea outbreaks in 12 provinces, 17 districts / cities. Jambi Province in 2017 the prevalence of diarrhea in infants is $43.79 \%$. In the city of Jambi the prevalence of diarrhea in children under five was 6.5\%. This study aims to look at the risk factors for diarrhea in infants. This research is a quantitative research with case control research design. Case samples were 30 people and control samples were 60 people, the comparison of the number of cases and controls was 1: 2, then the number of samples in the study were 90 toddlers. Data collection was done by filling out questionnaires with univariate and bivariate analysis using the chi square test. The analysis showed that there was a relationship between hand washing with soap and running water ( $p-$ value $=0.013 \&$ OR $=3,824)$, exclusive breastfeeding ( $p$-value $=0,000 \& O R=5,902)$, nutritional status ( $p$-value $=$ $0,001 \& O R=6,625)$, Latrine Quality ( $p$ - value $=0.001 \& O R=5,035)$ and source of clean water ( $p$-value $=0,009 \& O R=4,333$ ) on the incidence of diarrhea in children under five. Variables that are at risk for the incidence of diarrhea in infants are hand washing with soap and running water, exclusive breastfeeding, nutritional status, latrine quality and clean water sources

\section{Keywords: risk factors; diarrhea; Children}

\begin{abstract}
Abstrak
Permasalahan tentang diare masih merupakan masalah yang relatif besar. Tahun 2017 jumlah kejadian diare balita di Indonesia sebesar 40,07\% dan terjadi 21 kali kejadian luar biasa diare yang tersebar di 12 Provinsi, 17 kabupaten/kota. Provinsi Jambi tahun 2017 prevalensi diare pada balita sebesar 43,79\%. Di Kota Jambi prevalensi kejadian diare balita sebesar 6,5\%. Penelitian ini bertujuan untuk melihat faktor risiko kejadian diare pada balita. Penelitian ini merupakan penelitian kuantitatif dengan desain penelitian case control. Sampel kasus sebanyak 30 orang dan sampel kontrol sebanyak 60 orang, perbandingan jumlah sampel kasus dan kontrol adalah 1 : 2, maka jumlah sampel dalam penelitian sebanyak 90 balita. Pengumpulan data dilakukan dengan pengisian kuesioner dengan analisis univariat dan bivariat dengan menggunakan uji chi square. Hasil analisis menunjukkan bahwa terdapat hubungan mencuci tangan pakai sabun dan air mengalir ( $p-$ value $=0,013 \&$ $\mathrm{OR}=3.824)$, pemberian ASI eksklusif $(p-$ value $=0,000 \& \mathrm{OR}=5.902)$, status gizi $(p-$ value $=0,001 \& \mathrm{OR}=6.625)$, Kualitas Jamban $(p-$ value $=0,001 \& \mathrm{OR}=5.035)$ dan sumber air bersih $(p-$ value $=0,009 \& \mathrm{OR}=4.333)$ terhadap kejadian diare pada anak balita. Variabel yang berisiko terhadap kejadian diare pada balita adalah mencuci tangan pakai sabun dan air mengalir, pemberian ASI Eksklusif, Status Gizi, Kualitas Jamban dan Sumber Air Bersih.
\end{abstract}

Kata kunci : Faktor Risiko; Diare; Balita 


\section{Pendahuluan}

Diare merupakan masalah kesehatan masyarakat dan merupakan penyebab nomor satu kematian balita di seluruh dunia. Di Indonesia, diare adalah pembunuh balita nomor dua setelah ISPA (Infeksi Saluran Pernapasan Akut). Sementara UNICEF (Badan Perserikatan Bangsa-Bangsa untuk urusan anak) memperkirakan bahwa, setiap 30 detik ada satu anak yang meninggal dunia karena diare. Permasalahan tentang diare masih merupakan masalah yang relatif besar. Angka kesakitan diare sekitar 200-400 kejadian di antara 1000 penduduk setiap tahunnya. Dengan demikian di Indonesia dapat ditemukan sekitar 60 juta kejadian setiap tahunnya, sebagian besar (7080\%) dari penderita ini adalah anak di bawah lima tahun (Balita). Sebagian dari penderita (1$2 \%$ ) akan jatuh ke dalam dehidrasi dan kalau tidak segera ditolong 50-60\% di antaranya dapat meninggal (Widoyono, 2011).

Pada anak balita, diare lebih banyak menyebabkan kematian jika dibandingkan dengan AIDS, malaria dan campak (Arini, 2016). Berdasarkan data Riskesdas tahun 2018 menunjukkan bahwa prevalensi kejadian diare dari tahun 2013 ke 2018 mengalami peningkatan yaitu dari 2,4\% pada tahun 2013 meningkat menjadi 11,0\% pada tahun 2018 (Riskesdas, 2018). Di Provinsi Jambi, CFR diare untuk tahun 2013 adalah 8,83\%,tahun 2014 adalah 7,56\% tahun 2015 adalah 8,71\% dan pada tahun 2017 adalah 18,5 lalu mengalami penurunan menjadi 12,3\% pada tahun 2018 (Dinkes Provinsi Jambi, 2018).

Data Dinas Kesehatan Kota Jambi kejadian diare pada balita mengalami peningkatan. Kejadian diare pada tahun 2012 sebesar 1,5\% dan meningkat menjadi $6,5 \%$ pada tahun 2017 (Dinkes Kota Jambi, 2017). Berdasarkan data yang di peroleh dari Dinas Kesehatan Kota Jambi Tahun 2017. cakupan penderita diare pada anak usia balita di Kota Jambi sebanyak 3.042 balita, dimana $1,38 \%$ anak usia balita terkena diare yang pernah melakukan kunjungan kesehatan. Namun masih ada enam Puskesmas kejadian diare masih tinggi diatas batas yang telah ditetapkan (1,38\%). Urutan pertama Puskesmas Olak Kemang sebanyak 5,43\%, kemudian di ikuti oleh Puskesmas Aur Duri 3,19\%, Puskesmas Tanjung Pinang sebanyak 2,84\%, Puskesmas Tahtul Yaman sebanyak 2,38\%, Puskesmas Paal Merah II sebanyak 2,06\% dan Puskesmas Koni sebanyak $1,98 \%$.
Menurut WHO (2009) diare merupakan gejala infeksi yang disebabkan oleh berbagai mikroorganisme seperti bakteri, virus dan parasit, yang sebagian besar ditularkan melalui air yang terkontaminasi oleh tinja. Infeksi ini lebih sering terjadi ketika ada kekurangan air untuk minum, memasak dan membersihkan. Sumber air yang terkontaminasi kotoran manusia tersebut dapat berasal dari air limbah rumah tangga, tangki septik dan jamban. Penyakit diare dapat menyebar dari orang ke orang, dan dapat diperburuk oleh kebersihan yang rendah. Makanan merupakan penyebab utama diare bila diolah atau disimpan dalam kondisi yang tidah higienis dan air dapat mengkontaminasi makanan selama pengolahannya. Makanan dan minuman dapat terkontaminasi oleh mikroorganisme yang dibawa oleh serangga atau oleh tangan yang kotor.

Dampak diare yang terjadi pada balita selain kematian adalah dehidrasi, terganggunya pertumbuhan (gagal tumbuh), dan merupakan penyebab utama kekurangan gizi pada anak dibawah lima tahun (WHO, 2009). Perilaku yang dapat menyebabkan diare diantaranya: tidak memberikan air susu ibu (ASI) pada awal kehidupan bayi dan tidak diteruskan sampai usia dua tahun, penggunaan susu dengan botol yang tidak bersih, menyimpan makanan matang pada suhu kamar, menggunakan air minum yang sudah tercemar, tidak mencuci tangan dengan benar, serta pembuangan tinja yang tidak benar. Faktor pejamu yang dapat meningkatkan kerentanan terhadap penyakit diare diantaranya: kurang gizi, campak, imunodefiseinsi/imunosupresi. Faktor keluarga baik sosial ekonomi keluarga maupun jumlah balita dalam keluarga juga dapat mempengaruhi terjadinya diare pada balita. Karena diare merupakan penyakit yang berbasis lingkungan, maka faktor lingkunganpun berperan sangat besar terhadap kejadian diare dan tidak boleh diabaikan. Faktor risiko yang mempengaruhi kejadian diare yaitu faktor lingkungan (Sarana air bersih, jamban keluarga, kepadatan hunian rumah, sarana pembuangan air limbah dan pengelolaan sampah), faktor ibu (perilaku, pendidikan, pengetahuan) dan faktor balita (ASI eksklusif, imunisasi campak dan status gizi), serta faktor keluarga (jumlah balita dalam keluarga dan sosial ekonomi keluarga) (Depkes RI, 2007). 
Menurut Widoyono

(2011) menunjukkan bahwa kejadian diare pada balita dipengaruhi oleh beberapa faktor yaitu faktor lingkungan, tingkat pengetahuan ibu, sosial ekonomi dan makanan atau minuman yang dikonsumsi. Dari dator tersebut, faktor lingkungan merupakan faktor yang meningkatkan risiko balita mengalami diare. Faktor lingkungan terdiri dari pengolahan sampah, saluran limbah, jamban, maupun sumber air. Kebiasaan cuci tangan pada saat memasak makanan maupun setelah buang air besar juga merupakan faktor yang menyebabkan kejadian diare. Karena tangan jika tidak mencuci tangan setelah BAB akan memungkinkan terkontaminasi langsung. Menurut Lestari (2016), selain mencuci tangan pakai sabun dan air mengalir, kejadian diare juga dipengaruhi oleh pemberian air susu ibu (ASI), status gizi balita, jamban sehat, sumber air bersih.

Adapun hasil penelitian ini sejalan dengan Penelitian yang dilakukan oleh beberapa mahasiswa yang berada di berbagai Universitas yaitu : 1).Penelitian oleh Rohmah \& Syahrul, (2016) hubungan kebiasaan cuci tangan dan penggunaan jamban sehat dengan kejadian diare pada balita puskesmas sekardangan Kabupaten Sidoarjo. Hasil penelitian ini dapatkan ada hubungan hubungan yang signifikan antara kebiasaan cuci tangan $(P=0,006)$ dan penggunaan jamban sehat $(P=0,0014)$ dengan kejadian diare diare pada balita. Kesimpulan pada penelitian ini adalah kebiasaan cuci tangan dan penggunaan jamban sehat mempunyai hubungan yang signifikan dengan kejadian diare balita. Saran yang dapat diberikan kepada ibu balita adalah agar cuci tangan sebelum dan sesudah buang air serta sebelum menyiapkan makanan untuk anak 2). Penelitian oleh Susi \& Nurazila, (2018) faktor yang mempengaruhi kejadian diare pada balitadi wilayah kerja Puskesmas Rejosari Pekan Baru. Hasil penelitian terdapat hubungan faktor antara variabel independen dan variabel dependen yang artinya ha diterima dan ho ditolak dengan nilai $\mathrm{p}$-value $<\alpha=0,05$. pendidikan $\mathrm{p}$-value $=0,000$, pengetahuan $\mathrm{p}$-value $=0,000$, perilaku mencuci tangan $p$-value $=0,000$. maka disimpulkan terdapat hubungan faktor yang mempengaruhi kejadian diare pada balita di wilayah kerja Puskesmas Rejosari Pekanbaru tahun 2017.
Puskesmas Olak Kemang merupakan puskesmas yang wilayah kerjanya sebagian besar berada di pinggiran sungan Batanghari. Perilaku masyarakat dalam mencuci tangan pakai sabun dan air mengalir masih kurang baik, padahal puskesmas sudah bekerja secara maksimal dalam memberikan informasi terkait dengan pentingnya cuci tangan pakai sabun. Masyarakat juga memiliki kebiasaan dimana masih memanfaatkan air sungai dalam mandi cuci kakus (MCK). Karena berada di sekitar sungai, masyarakat juga memiliki kebiasaan dalam buang air besar (BAB) di sungai.

Terkait dengan pekerjaan, dimana wilayah kerja puskesmas Olak Kemang merupakan daerah industri tekstil yaitu batik, sebagian besar ibu rumah tangga bekerja sebagai pembatik sehingga ada beberapa ibu tidak memberikan ASI Eksklusif kepada anak. Penelitian tentang faktor risiko kejadian diare pada balita sudah banyak dilakukan penelitian. Perbedaan penelitian ini dengan penelitian lain adalah pada sampel/responden dimana sampel penelitian ini adalah masyarakat yangtinggal di sekitar aliran sungai Batanghari yang terletak ditengah kota.

\section{Metode}

Penelitian ini merupakan penelitian survei observasional dengan pendekatan kasus kontrol. Populasi penelitian adalah seluruh ibu yang memiliki balita di wilayah kerja puskesmas Olak Kemang. Sampel penelitian terdiri dari sampel kasus dan sampel kontrol. Sampel kasus adalah ibu yang memiliki balita yang didiagnosa oleh dokter menderita diare pada bulan Juli-September 2018 sebanyak 30 orang. Dan sampel kontrol adalah ibu yang memiliki balita yang tidak didiagnosa oleh dokter menderita diare. Perbandingan jumlah sampel kasus dan kontrol adalah 1:2 sehingga jumlah sampel kontrol sebanyak 60 orang. Penelitian dilakukan pada tanggal $02 \mathrm{~s} / \mathrm{d} 30$ November 2018 di wilayah kerja Puskesmas Olak Kemang. Sumber data diperoleh dari rekam medis Puskesmas Olak Kemang. Teknik pengumpulan data dengan cara observasi dan wawancara. Instrumen yang digunakan adalah pedoman observasi dan kuesioner. Data dianalisis secara univariat dan bivariat menggunakan uji chi-square. 
Pengambilan sampel dilakukan dengan Kriteria matching antar kasus dan kontrol dilihat dari :

a. Status rumah (milik sendiri \& kontakan).

b. Kondisi rumah (Papan \& permanen).

c. Tetangga dari kasus.

Pengukuran variabel penelitian ini adalah sebagai berikut :

a. Kejadian Diare

Cara pengukurannya dengan melihat dokumen hasil diagnosa dokter/petugas paramedis terlatih. Data yang ada dikategorikan menjadi kasus (balita yang menderita diare) dan kontrol (balita yang tidak menderita diare)

b. Cuci tangan pakai sabun dan air mengalir

Alat ukur yang digunakan adalah kuesioner dengan cara melakukan wawancara kepada responden. Data yang dikumpulkan dikategorikan menjadi kurang baik dan baik, kurang baik jika tidak mencuci tangan dengan sabun dan air mengalir. Baik jika mencuci tangan dengan sabun dan air mengalir.

c. Pemberian ASI

Alat ukur yang digunakan adalah kuesioner dengan cara melakukan wawancara kepada responden. Data yang dikumpulkan dikategorikan menjadi kurang baik dan baik. Kurang baik jika tidak memberikan ASI Eksklusif dan baik jika memberikan ASI Eksklusif.

d. Status Gizi

Pengumpulan satus gizi diukur dengan melakukan pengukuran tinggi badan dan berat badan menggunakan timbangan dan meteran. Data dikategorikan menjadi tidak normal dan normal. Tidak normal apabila kurus ( -3 sampai <-2 SD) atau gemuk ( $>1$ SD sampai 2 SD), normal apabila -2 SD sampai 1 SD.

e. Kualitas Jamban

Data dikumpulkan dengan melakukan observasi menggunakan pedoman observasi kemudian dikategorikan menjadi tidak memenuhi syarat dan memenuhi syarat. Tidak memenuhi syarat jika skor $\geq$ median (7) dan memenuhi syarat jika skor $<$ median (7)

f. Sumber air bersih

Data dikumpulkan dengan melakukan pemeriksaan air menggunakan kuesioner kemudian dikategorikan menjadi tidak memenuhi syarat dan memenuhi syarat. Tidak memenuhi syarat jika tidak berbau, tidak berasa, tidak berwarna dan tidak keruh atau jernih dan memenuhi syarat jika tidak berbau, tidak berasa, tidak berwarna dan tidak keruh atau jernih

\section{Hasil}

Hasil analisis univariat menunjukkan bahwa sebaayak $74,5 \%$ responden memiliki perilaku baik dalam mencuci tangan pakai sabun dan air mengalir, 57,8\% responden baik dalam pemberian ASI, $76,7 \%$ responden memiliki balita dengan status gizi normal, $55,6 \%$ responden memiliki kualitas jamban memenuhi syarat dan sebanyak $77,8 \%$ responden memiliki sumber air bersih memenuhi syarat. Data tersebut dapat dilihat pada tabel 1.

Bedasarkan hasil analisis adanya hubungan mencuci tangan pakai sabun dan air mengalir terhadap kejadian diare pada anak balita di peroleh nilai $p$-value $=0,013(\mathrm{p}<0,05)$, artinya Ho ditolak sehingga ada hubungan mencuci tangan pakai sabun dan air mengalir terhadap kejadian diare pada anak balita.

Hasil analisis adanya hubungan pemberian ASI Eksklusif terhadap kejadian diare pada anak balita di peroleh nilai $p$-value $=0,000(p<0,05)$, artinya Ho ditolak sehingga ada hubungan pemberian ASI Eksklusif terhadap kejadian diare pada anak balita.

Hasil analisis adanya hubungan status gizi terhadap kejadian diare pada anak balita di peroleh nilai $p$-value $=0,001(\mathrm{p}<0,05)$, artinya Ho ditolak sehingga ada hubungan status gizi terhadap kejadian diare pada anak balita.

Hasil analisis adanya hubungan kualitas jamban terhadap kejadian diare pada anak balita di peroleh nilai $p$-value $=0,001$ $(\mathrm{p}<0,05)$, artinya Ho ditolak sehingga ada hubungan kualitas jamban terhadap kejadian diare pada anak balita.

Hasil analisis adanya hubungan sumber air bersih terhadap kejadian diare pada anak balita di peroleh nilai $p$-value $=$ $0,009(\mathrm{p}<0,05)$, artinya Ho ditolak sehingga ada hubungan sumber air bersih terhadap kejadian diare pada anak balita. Data tersebut dapat dilihat pada tabel 2 . 


\section{Pembahasan}

Hasil hubungan antara cuci tangan pakai sabun dan air mengalir menunjukkan bahwa ada hubungan yang signifikan antara mencuci tangan pakai sabun dan air mengalir terhadap kejadian diare pada anak balita. Hasil penelitian ini sejalan dengan penelitian Muliawan (2008), yang menyatakan bahwa terdapat hubungan antara perilaku cuci tangan dengan kejadian diare pada anak umur 6 - 12 tahun diwilayah kerja Puskesmas Kersana Kabupaten Brebes. Responden yang tidak memiliki perilaku cuci tangan yang memenuhi syarat kesehatan (tidak cuci tangan sebelum makan dan sesudah buang air lebih berisiko terkena diare.

Penelitian ini juga sejalan dengan penelitian yang dilakukan oleh Kusumawati (2012) dimana kebiasaan mencuci tangan merupakan faktor risiko terhadap diare pada balita usia 1 - 3 tahun studi kasus di Desa Tegowanu Wetan Grobogan. Berdasarkan laporan Subdit Surveilans dan Respon KLB Ditjen PP dan PL tahun 2010, menyatakan bahwa faktor perilaku orang tua balita menjadi faktor yang penting dalam menurunkan angka kesakitan diare pada balita, dapat diartikan bahwa kejadian diare pada balita sangat berhubungan erat dengan perilaku yang dimiliki oleh ibunya

Menurut Depkes RI (2009), bahwa sekitar 30 penelitian terkait cuci tangan dengan sabun dapat memangkas angka penderita diare hingga separuh. Penyakit diare seringkali diasosiasikan dengan keadaan air, namun secara akurat sebenarnya harus diperhatikan juga penanganan kotoran manusia seperti tinja dan air kencing, karena kuman-kuman penyakit penyebab diare berasal dari kotoran-kotoran ini. Kuman-kuman penyakit ini membuat manusia sakit ketika mereka masuk mulut melalui tangan yang telah menyentuh tinja, air bersih yang terkontaminasi, makanan mentah, dan peralatan makan yang tidak dicuci terlebih dahulu atau terkontaminasi akan temapat makannya yang kotor.

Menurut asumsi peneliti kebiasan cuci tangan, perilaku cuci tangan buruk berhubungan erat dengan peningkatan kejadian diare dan penyakit yang lain. Responden memiliki perilaku cuci tangan baik dikarenakan puskesmas Olak Kemang pernah mengikuti lomba PHBS rumah tangga tingkat lokal sehingga kegiatan tersebut mempengaruhi perilaku cuci tangan responden. Responden yang memiliki perilaku cuci tangan kurang baik dikarenakan memiliki kebiasaan yang kurang baik dalam membuang air besar. Mereka masih membuang air besar di sungai karena rumah mereka berada ditepi sungai sehingga mereka tidak mencuci tangan dengan sabun setelah buang air besar.

Perilaku cuci tangan yang baik dapat menghindarkan diri dari diare hal ini dikarenakan dengan mencuci tangan dengan baik setidaknya dapat menghilangkan atau mengurangi kuman yang ada ditelapak tangan balita sehingga dapat mengurangi risiko untuk terjadinya penyakit diare. Hasil hubungan antara pemberian ASI Eksklusif dengan kejadian diare menunjukkan bahwa ada hubungan antara pemberian Asi Eksklusif dengan kejadian diare pada balita.

Perilaku sehat yang perlu diperhatikan dalam penyebaran penyakit diare yaitu perilaku yang memudahkan penyebaran penyakit melalui faecal oral diantaranya adalah perilaku mencuci tangan, perilaku pengelolaan makanan, perilaku pemberian ASI eksklusif dan perilaku penyehatan lingkungan. Perilaku ibu dalam mencuci tangan perlu mendapat perhatian, karena ibu yang tidak mencuci tangan sebelum makan atau sebelum menyuapkan makanan pada anak, setelah buang air besar, serta tidak mencuci tangan sebelum menyiapkan makanan atau menyiapkan susu untuk anak, dapat meningkatkan resiko terjadinya penyakit diare (Depkes, RI 2007). Perilaku cuci tangan pakai sabun (CTPS) dapat mencegah berbagai penyakit infeksi, perilaku CTPS dapat menurunkan hampir separuh kasus diare (Depkes RI, 2010). Pencucian alat makan, cara pengolahan makanan, dan cara penyimpanan makanan sangat berperan penting dalam mencegah terjadinya suatu penyakit, terutama diare.

Menurut asumsi peneliti berdasarkan data tersebut didapatkan hasil bahwa kejadian diare pada bayi yang tidak mendapat ASI eksklusif lebih tinggi dibandingkan dengan bayi yang mendapat ASI eksklusif. Responden sudah baik dalam memberikan ASI Eksklusif, hal tersebut dikarenakan responden sudah memiliki pengetahuan yang baik. Pengetahuan yang dimiliki oleh responden dalam kategori 
baik karena petugas Puskesmas Olak Kemang memberikan penyuluhan setiap bulan pada saat kegiatan posyandu balita. Selain itu bidan juga memberikan konseling terkait dengan pentingnya ASI pada saat responden melakukan kunjungan antinatalcare. Sedangkan responden yang memiliki pengetahuan kurang baik dikarenakan sibuk bekerja untuk membatu suami sehingga pada saat kegiatan peyuluhan mereka tidak datang.

Upaya-upaya yang dapat dilakukan untuk mencegah terjadinya diare bagi balita yang tidak mendapatkan ASI Eksklusif yaitu dengan memperhatikan setiap makanan yang dikonsumsi oleh balita baik dari segi kebersihan, gizi ataupun kandungan makanan yang dikonsumsi balita serta mengatur pola makan balita dengan baik dan tidak membiarkan balita mengkonsumsi makanan dari luar atau makanan instan.

Untuk mengurangi angka kesakitan diare pada balita akibat perilaku ibu yang buruk diperlukan peningkatan pengetahuan ibu balita tentang cara mencuci tangan yang benar, cara pengelolaan makanan yang memenuhi syarat kesehatan, dan menekankan pentingnya imunisasi campak dan pemberian ASI pada bayi terutama pada saat 6 bulan pertama setelah lahir

Hasil analisis hubungan status gizi dengan kejadian diare menunjukkan bahwa responden yang memiliki status gizi tidak normal berisiko 7 kali lebih tinggi menderita diare jika dibandingkan dengan responden yang memiliki status gizi rendah. Kurang gizi merupakan penyakit yang tidak menular yang terjadi pada sekelompok masyarakat. Beratnya penyakit, lama dan risiko kematian karena diare akan meningkat pada balita yang mengalami kurang gizi terutama gizi buruk (Depkes RI, 2007), karena dengan adanya kekurangan gizi pada balita maka balita akan rentan terhadap berbagai penyakit akibat daya tahan tubuhnya yang kurang. Kekurangan gizi, merupakan kegagalan mencapai kandungan gizi yang dibutuhkan, sehingga dapat mengurangi kesehatan fisik dan mental. Kekurangan gizi secara umum yang ditandai dengan keterlambatan pertumbuhan, berat badan di bawah normal, pertumbuhan yang terhambat, kekurangan mikronutrien, seperti vitamin A, zinc, yodium, dan asam folic. Risiko penyakit yang mengancamnya diantaranya adalah penyakit infeksi terutama diare.
Penelitian ini sesuai dengan yang telah dilakukan oleh Dewi (2011) bahwa dari hasil penelitian ketiga peneliti tersebut sebelumnya didapat antara status gizi dan kejadian diare pada balita mempunyai hubungan yang signifikan, artinya bahwa balita dengan status kurang gizi mempunyai risiko untuk terkena diare dibandingkan dengan balita yang mempunyai status gizi baik.

Hasil penelitian Rakhmawati (2008), menunjukkan semakin baik status gizi balita maka semakin besar peluang tidak menderita diare dan penyakit infeksi. Menurut Nuryanto (2012), status gizi baik umumnya akan meningkatkan resistensi tubuh terhadap penyakit-penyakit infeksi. Penelitian ini sesuai dengan penelitian yang dilakukan oleh Adisasmito (2007) yang melakukan kajian terhadap beberapa faktor risiko diare di Indonesia menyimpulan bahwa status gizi yang rendah pada bayi dan balita merupakan faktor resiko terjadinya diare. Status gizi buruk dapat mempengaruhi kejadian dan lamanya diare.

Sebagian besar responden memiliki status gizi baik dikarenakan tingkat ekonomi responden tergolong ekonomi menengah keatas, responden memiliki pekerjaan sehingga menambah penghasilan perbulan dan dapat memenuhi kebutuhan sehari-hari. selain itu responden menanam sayuran berada diperkarangan rumah yang dapat dimanfaatkan dalam penuhan gizi keluarga. Responden yang memiliki status gizi kurang dikarenakan sosial ekonomi rendah sehingga tidak dapat memenuhi kebutuhan hidup sehari-hari.

Pada prinsipnya penyuluhan oleh petugas harus tetap dilakukan untuk dapat mengurangi atau mencegah kejadian diare melalui pendidikan gizi di masyarakat terutama pada ibu balita. Pendidikan gizi merupakan salah satu unsur penting dalam meningkatkan status gizi masyarakat untuk jangka panjang. Untuk meningkatkan pemahaman dan kemampuan masyarakat mengkonsumsi makanan, perlu dimasyarakatkan perilaku yang baik dan benar sesuai dengan kaidah Ilmu Gizi. Perilaku ini diwujudkan dalam bentuk pesan dasar gizi seimbang, yang pada hakekatnya merupakan perilaku konsumsi makanan yang baik dan sesuai untuk bangsa Indonesia. Upaya- upaya perbaikan gizi dapat diintegrasikan ke dalam berbagai program yang sudah ada seperti pertanian, ketahanan pangan, perkembangan ekonomi, serta 
air dan sanitasi. Karena masalah kekurangan gizi merupakan sebab dan akibat dari berbagai masalah kesehatan dan tidak bisa diperbaiki hanya oleh satu pihak saja (Gibney, 2004).

Hubungan antara kualitas jamban dan kejadian diare menunjukkan bahwa responden yang memiliki kualitas jamban tidak memenuhi syarat berisiko 5 kali lebih tinggi menderita diare jika dibandingkan dengan responden yang memiliki kualitas jamban memenuhi syarat. Hasil Survey Demografi Kesehatan Indonesia (SDKI) pada tahun 2012, dikatakan bahwa balita yang tinggal di rumah dengan fasilitas jamban yang tidak memenuhi syarat memiliki persentase diare lebih tinggi dibandingkan dengan balita yang tinggal di rumah dengan fasilitas jamban yang memenuhi syarat.

Kebiasaan responden dalam buang air besar adalah di sungai karena wilayah tersebut berada di aliran sungai Batanghari. Masyarakat sudah membuat jamban di dalam rumah tetapi karena kebiasaan mereka yang buang air besar di sungai sehingga jamban keluarga jarang digunakan. Pada saat penelitian, peneliti hanya melakukan observasi jamban keluarga, karena jamban jarang digunakan maka terlihat memenuhi syarat.

Jamban merupakan salah satu komponen penting yang harus ada disetiap rumah, jamban digunakan sebagai tempat pembuangan tinja. Memanfaatkan jamban yang tersedia merupakan salah satu permasalahan yang sering ditemui dimasyarakat. Perilaku masyarakat yang masih rendah akan pentingnya memanfaatkan jamban yang tersedia, dapat menyebabkan berbagai masalah muncul salah satunya yaitu masalah kesehatan. Sarana pembuangan tinja yang tidak memenuhi syarat kesehatan dapat menjadi penyebaran penyakit atau tempat berkembang biak lalat dan dapat meningkatkan risiko kesehatan (Kemenkes RI, 2013).

Tinja merupakan bahan buangan yang dikeluarkan oleh tubuh, dalam tinja terkandung sekitar dua milyar faecal coliform dan 450 juta faecal Streptoccoci (Ehler and Steel dalam Sarudji, 2010). Berdasarkan hal tersebut maka tersedianya sarana jamban yang memenuhi syarat di dalam rumah tangga merupakan bagian yang sangat penting, karena sarana jamban yang tidak memenuhi syarat dapat menyebabkan tercemarnya air tanah dan sumber air di sekitarnya. Jarak bak pengurai dengan sumber air di sekitarnya adalah 10 meter untuk tanah berpasir dan 15 meter untuk tanah kapur atau liat. Berdasarkan hasil observasi yang dilakukan oleh peneliti, sebagian besar responden sudah memiliki jamban leher angsa tetapi pembuangan tinjanya masih dialirkan ke selokan atau sungai, sehingga hal tersebut dapat menyebabkan tinja terjangkau oleh serangga terutama lalat, lalat akan terbang dan hinggap pada makanan yang akan dikonsumsi oleh manusia, sehingga makanan sudah terkontaminasi oleh bibit penyakit, terutama diare (Soemirat, 2007).

Hasil penelitian sejalan dengan Mashur (2013) menunjukan bahwa sebagian besar kondisi jamban di Kelurahan Terjun belum memenuhi persyaratan jamban sehat yaitu sekitar $70 \%$ dari jumlah resonden sementara yang memenuhi syarat sebanyak $30 \%$. Jamban merupakan salah satu dari sarana sanitasi yang penting dan berkaitan dengan kejadian diare. Jamban yang tidak saniter akan mempermudah terjadinya penularan diare karena kemungkinan adanya mata rantai penularan penyakit dari tinja yang mudah berkembang biak ke penjamu yang baru dan dapat mencemari sumber air.

Dari gambaran keadaan jamban keluarga, maka untuk meningkatkan kepemilikan dan pemanfaatan jamban keluarga di wilayah Kerja Puskesmas Olak Kemang diperlukan adanya motivasi dan pembinaan yang disesuaikan dengan kondisi tingkatan pengetahuan masyarakat setempat sehingga semaksimal mungkin dapat membangkitkan kesadaran dan peranan masyarakat dalam upaya pemanfaatan jamban keluarga selain itu perlu membentuk dan membangun kembali kelompok-kelompok kegiatan masyarakat seperti Kelompok Kerja Kesehatan Lingkungan (Pokja Kesling) di setiap RT untuk kembali menggerakkan minat masyarakat dalam upaya peningkatan pemanfaatan jamban keluarga.

Hasil analisis sumber air bersih dengan kejadian diare pada balita menunjukkan bahwa responden yang memiliki sumber air bersih tidak memenuhi syarat berisiko 4 kali lebih tinggi menderita diare jika dibandingkan dengan responden yang memiliki sumber air bersih memebuhi syarat. Sumber air bersih yang digunakan oleh masyarakat diwilayah kerja Puskesmas Olak Kemang mayoritas 
menggunakan air bersih yang berasal dari air sumur gali, sumur bor dan PDAM. Ada hubungan antara kualitas fisik air bersih dengan kejadian diare pada bayi. Kualitas fisik air bersih yang buruk membuat bayi rentang terkena diare.

Hasil penelitian sejalan dengan penelitian Melviana (2013), bahwa sumber air bersih warga yang memenuhi syarat ada sebanyak 63,3\% dari responden sementara yang tidak memenuhi syarat ada sebanyak $36,7 \%$. kualitas air dapat ditentukan oleh kehadiran dan jumlah bakteri E.coli di dalamnya. E.coli hidup dalam saluran pencernaan makanan manusia ataupun hewan berdarah panas. Oleh karena itu, bakteri Coli, merupakan indikator pencemaran tinja di dalam air.

Hasil penelitian ini sesuai dengan penelitian yang dilakukan oleh Dewi (2011) di Kabupaten Badung yang menyatakan bahwa balita yang menggunakan sumber air bersih dengan kategori tidak memenuhi syarat mempunyai risiko 3,28 kali untuk menderita diare dibandingkan dengan balita yang keluarganya menggunakan sumber air bersih memenuhi syarat. Hasil penelitian ini sesuai dengan penelitian yang telah dilakukan sebelumnya oleh Zulkifli, (2017). Penelitian tersebut berjudul Hubungan Cakupan Air Bersih Dan Jamban Keluarga Dengan Prevalensi Diare Di Kabupaten Sambas Tahun 2016. Kesimpulan yang diperoleh dari penelitian tersebut menunjukkan adanya hubungan antara cakupan air bersih dengan prevalensi diare, dengan nilai probabilitas yang diperoleh hasil penelitian yaitu sebesar 0,027 .

Penelitian ini juga sejalan dnegan penelitian Bumolo, (2012) Hasil analisis data statistik menunjukkan bahwa sarana penyediaan air bersih yang digunakanada hubungan dengan kejadian diare pada balita di wilayah kerja Puskesmas Pilolodaa Kecamatan Kota Barat Kota Gorontalo. Dari hasil uji bivariat diperoleh nilai $\mathrm{p}$ value $=0,005(p<0,05)$. Dengan demikian dapat disimpulkan Ha diterima, sehingga ada hubungan antara sarana penyediaan air bersih dengan kejadian diare pada anak balita.

Air merupakan salah satu kebutuhan vital bagi setiap orang guna menjamin kesehatan tubuh maupun untuk kelangsungan hidup. Tidak tersedianya air bersih yang memenuhi standar kesehatan dapat berpotensi menyebabkan penyakit diare. Air sangat mungkin tercemar karena air menempuh perjalanan yang cukup panjang dari sumbernya sampai siap digunakan di tingkat rumah tangga. Pencemaran pada air, sangat memudahkan penyebaran diare apalagi air yang tercemar kuman diare tersebut air yang siap untuk diminum. Pencemaran air minum dirumah dapat terjadi apabila air minum ditempatkan pada tempat yang tidak bersih, atau tidak ditutup dengan baik, serta apabila tangan yang tercemar kuman menyentuh air pada saat mengambil air dari tempatnya (Depkes 2007).

Sumur adalah sumber air bersih yang banyak digunakan, kontaminasi air sumur berasal dari sumber pencemar di sekitarnya. Pencemaran air dapat terjadi pada sumur disebabkan karena jarak sumur dengan tangki septik yang kurang dari 10 meter, sumber air dekat dengan kandang hewan, dan pembuatan sumur yang tidak memenuhi standar yang ditentukan menurut kesehatan. Mata air juga banyak digunakan sebagai sumber air bersih oleh masyarakat, terutama masyarakat yang berada di daerah pegunungan seperti halnya di daerah yang dilakukan penelitian oleh peneliti. Pencemaran dapat terjadi karena mata air yang tidak terlindung sehingga memungkinkan air tercemar dari air larian, debu, serangga, binatang liar, ternak dan sebagainya (Sarudji, 2010).

Menurut asumsi peneliti sebagian besar diare disebabkan oleh bakteri, salah satu media penyebaran diare adalah air bersih yang digunakan oleh responden. Terutama pada sumur dangkal, konstruksinya harus dilengkapi dengan cincin sumur sedalam 3 meter, bibir sumur minimal 1 meter dari permukaan tanah serta memiliki tutup untuk mencegah terjadinya pencemaran sedangkan diwilayah kerja Puskesmas Olah Kemang sebagian masyarakat menggunakan sumber air bersih yang dari sumur gali yang tidak memiliki penutup atau tidak tertutup dan air sumurnya keruh yang berwarna abu-abu. Oleh sebab itu, untuk pemutusan rantai penularan diare salah satu intervensinya adalah penyediaan air bersih yang memenuhi syarat kesehatan termasuk lokasi sumber air bersih seta tempat penyimpanan untuk mencegah terjadinya pencemaran diare. Maka upaya yang dapat dilakukan oleh masyarakat untuk menjaga kebersihan sumber sir bersih yaitu dengan membuat penutup sumur atau membuat atap sumur sehingga sumber sir bersih terjada kualitasnya. 


\section{Kesimpulan dan Saran}

Kesimpulan dari penelitian ini adalah adanya hubungan mencuci tangan pakai sabun dan air mengalir terhadap kejadian diare pada anak balita di wilayah kerja Puskesmas Olak Kemang tahun 2018 nilai $p$-value $=0,013(\mathrm{p}<$ 0,05 dan OR=3.824); Adanya hubungan pemberian ASI Eksklusif terhadap kejadian diare pada anak balita di wilayah kerja Puskesmas Olak Kemang tahun 2018 nilai $p$ value $=0,000(\mathrm{p}<0,05$ dan $O R=5.902)$; Adanya hubungan status gizi terhadap kejadian diare pada anak balita di wilayah kerja Puskesmas Olak Kemang tahun 2018 dengan $p$-value = 0,001 ( $\mathrm{p}<0,05$ dan OR=6.625); Adanya hubungan kualitas jamban terhadap kejadian diare pada anak balita di wilayah kerja Puskesmas Olak Kemang tahun 2018 nilai $p$ value $=0,001(\mathrm{p}<0,05$ dan $O R=5.035)$; Analisis hubungan sumber air bersih bterhadap kejadian diare pada anak balita di wilayah kerja Puskesmas Olak Kemang tahun 2018 nilai $p$ value $=0,009(\mathrm{p}<0,05$ dan $O R=4.333)$.

Saran yang diberikan adalah Puskesmas dapat meningkatkan promosi kesehatan untuk pencegahan diare dalam tatanan rumah tangga. Penerapan perilaku hidup bersih dan sehat perlu pendampingan lansung pada keluarga yang balitanya terkena diare terutama dalam pemberian ASI eksklusif, menggunakan air bersih, penggunaan jamban dan perilaku mencuci tangan dengan sabun. Oleh karena itu, pemetaan SDM untuk mendampingi penerapan perilaku hidup bersih dan sehat seperti perawat atau kader perlu dilakukan pihak puskesmas. Pelaksanaan monitoring dan evaluasi untik pendampingan penerapan PHBS keluarga juga harus diperhatikan. Untuk itu, pihak puskesmas juga perlu menyediakan media-media dalam melakukan promosi kesehatan seperti pemberian contoh langsung menggunakan demostrasi atau pemutaran video yang memberikan gambaran perilaku hidup bersih dan sehat keluaraga dalam pemcegahan diare pada balita.

\section{Daftar Pustaka}

Adisasmito, W. 2007. Fakto Rrisiko Diare Pada Bayi dan Balita di Indonesia. Systematic Review Penelitian Akademik Bidang Kesehatan Masyarakat. Makara Kesehatan Vol. 11, No. 1, Juni: 1-10
Arini, A, P. 2016. Diare Pencegahan dan Pengobatannya. Yogyakarta: Nuha Medika

Bumolo (2012). Sarana Penyediaan Air Bersih Yang Digunakan Ada Hubungan Dengan Kejadian Diare Pada Balita Di Wilayah Kerja Puskesmas Pilolodaa Kecamatan Kota Barat Kota Gorontalo. Jurnal Kesehatan Lingkungan Vol 2 No 4

Depkes RI. (2007). Keputusan Menteri Kesehatan Republik Indonesia Nomor: 1216/Menkes/SK/XI/2001 Tentang Pedoman Pemberantasan Penyakit Diare. Jakarta: Direktorat Jendral Pemberantasan Penyakit Menular dan Penyehatan Lingkungan Departemen Kesehatan Republik Indonesia.

Depkes RI. 2009. Rencana Pembangunan Jangka Panjang Bidang Kesehatan 2005-2025. Jakarta: Dinkes RI

Depkes RI. 2010. Keputusan Menteri Kesehatan Republik Indonesia Nomor 492/MENKES/PERIIV/2010 tentang Persyaratan Kualitas Air Minum. Jakarta: Direktorat Jendral Pemberantasan Penyakit Menular dan Penyehatan Lingkungan Departemen Kesehatan Republik Indonesia

Dewi, E.P. 2011. Faktor Faktor Yang Berhubungan Dengan Kejadian Diare Pada Balita Di Wilayah Kerja UPT Puskesmas Mengwi, Kecamatan Mengwi, Kabupaten Badung, Provinsi Bali Tahun 2011 (Skripsi). Fakultas Kesehatan Masyarakat Program Sajana Kesehatan Masyarakat, Universitas Indonesia

Dinkes Provinsi Jambi. 2018. Profil Kesehatan Provinsi Jambi Tahun 2017. Jambi : Dinkes Provinsi Jambi

Dinkes Kota Jambi. 2018. Profil Kesehatan Kota Jambi tahun 2017. Jambi : Dinkes Kota Jambi

Gibney, G. 2004. Buku Panduan Pemulihan Gizi Anak Malnutrisi, Child Survival Collaboration and Resources Group Nutrition Working Group. Diterjemahkan oleh Project Concern International / PCI Indonesia dan diperbanyak oleh "Jejaring PD Indonesia"

Kemenkes RI. 2011. Buletin Jendela Data dan Informasi Kesehatan. Jakarta: Kemenkes RI

Kemenkes RI. 2013. Profil Kesehatan Indonesia Tahun 2013. Jakarta : Kemenkes RI

Kemenkes RI. 2017. Profil Kesehatan Indonesia Tahun 2017. Jakarta : Kemenkes RI 
Kusumawati. 2012. Faktor-Faktor yang Mempengaruhi Kejadian Pasien Diare pada Anak di RSUD Majenang Kabupaten Cilacap Tahun 2008. Jurnal Ilmiah Kesehatan Keperawatan. Volume.5

Lestari, Titik, (2016). Asuhan Keperawatan Anak. Yogyakarta: Nuha Medika

Mashur. 2013. Hubungan Kualitas Sanitasi Lingkungan dan Bakteriologis Air Bersih Terhadap Kejadian Diare pada Balita di Wilayah Kerja Puskesmas Adiwerna Kabupaten Tegal. Jurnal Kesehat Masyarakat. Volume. 4, Nomor. 3

Melviana. 2013. Hubungan Sanitasi Jamban dan Air Bersih dengan Kejadian Diare pada Balita di Kelurahan Terjun Kecamatan Medan Marelan Kota Medan. Skripsi : Program Sarjana Fakultas Kesehatan Masyarakat. Universitas Sumatera Utara Departemen Kesehatan Lingkungan

Muliawan. 2008. Beberapa Faktor yang Berhubungan dengan Kejadian Diare Balita di Desa Sigayam Wilayah Kerja Puskesmas Wonotunggal Kabupaten Batang. Skripsi: Fakultas Kesehatan Masyarakat, Universitas Diponegoro

Nuryanto. 2012. Hubungan Status Gizi terhadap Terjadinya Penyakit Infeksi pada Balita. Jurnal Pembangunan Manusia Vol. 6.No. 2.
Rakhmawati, D. 2008. Hubungan antara Status Gizi dengan Kejadian Diare pada Balita di Unit Rawat Jalan Anak RSU Dr. Soetomo Surabaya. Bulletin Penelitian RSU dr. Soetomo. Vol. 10. No. 3

Riskesdas. 2018. Riset Kesehatan Dasar Tahun 2018. Jakarta : Kemenkes RI

Rohmah, Nikmatur \& Syahrul, Fariani. 2016. Hubungan Kebiasaan Cuci Tangan Dan Penggunaan Jamban Sehat Dengan Kejadian Diare Pada Balita Puskesmas Sekardangan Kabupaten Sidoarjo. Jurnal Berkala Epidemiologi. Volume 5 Nomor 1

Sarudji. 2010. Kesehatan Lingkungan. Bandung: Karya Putra Darwati

SDKI. 2012. Survei Demografi Kesehatan Indonesia Tahun 2012. Jakarta: Kemenkes RI

Soemirat. (2007). Kesehatan Lingkungan. Cetakan ketujuh Yogyakarta: Gadjah Mada University Press

WHO. 2009. WHO guidelines on hand hygiene in health care. WHO Library Cataloguing-inPublication Data

Widoyono. 2011. Penyakit Tropis Epidemiologi, Penularan, Pencegahan Pemberantasananya. Jakarta: Erlangga

Zulkifli. 2017. Hubungan Cakupan Air Bersih Dan Jamban Keluarga Dengan Prevalensi Diare Di Kabupaten Sambas. Jurnal Vol 5 No 5

Tabel 1

Hasil Analisis Univariat

\begin{tabular}{|c|c|c|c|}
\hline No & Variabel & $\mathbf{n}$ & $\%$ \\
\hline \multirow[t]{3}{*}{1} & Mencuci Tangan & & \\
\hline & Kurang Baik & 23 & 25,5 \\
\hline & Baik & 67 & 74,5 \\
\hline \multirow[t]{3}{*}{2} & Pemberian ASI & & \\
\hline & Kurang baik & 38 & 42,2 \\
\hline & Baik & 52 & 57,8 \\
\hline \multirow[t]{3}{*}{3} & Status Gizi & & \\
\hline & Tidak Normal & 21 & 23,3 \\
\hline & Normal & 69 & 76,7 \\
\hline \multirow[t]{3}{*}{4} & Kualitas Jamban & & \\
\hline & Tidak Memenuhi Syarat & 40 & 44,4 \\
\hline & Memenuhi Syarat & 50 & 55,6 \\
\hline \multirow[t]{3}{*}{5} & Sumber Air Bersih & & \\
\hline & Tidak Memenuhi Syarat & 20 & 22,2 \\
\hline & Memenuhi Syarat & 70 & 77,8 \\
\hline
\end{tabular}

Sumber : Data Primer 2018 
Tabel 2

Distribusi Frekuensi Faktor Penyebab Diare

\begin{tabular}{|c|c|c|c|c|c|c|c|c|}
\hline \multirow{3}{*}{ Variabel Independen } & \multicolumn{4}{|c|}{ Diare } & \multirow{2}{*}{\multicolumn{2}{|c|}{ Total }} & \multirow{3}{*}{$\begin{array}{c}\text { p- } \\
\text { value }\end{array}$} & \multirow{3}{*}{$\begin{array}{c}\text { OR } \\
(95 \% \mathrm{CI})\end{array}$} \\
\hline & \multicolumn{2}{|c|}{ Ya } & \multicolumn{2}{|c|}{ Tidak } & & & & \\
\hline & $\mathbf{n}$ & $\%$ & $\mathbf{n}$ & $\%$ & $\mathbf{n}$ & $\%$ & & \\
\hline Mencuci Tangan & & & & & & & \multirow{3}{*}{0,013} & \multirow{3}{*}{3.824} \\
\hline Kurang Baik & 13 & 43.3 & 10 & 16.7 & 13 & 43.3 & & \\
\hline Baik & 17 & 56.7 & 50 & 83.3 & 17 & 56.7 & & \\
\hline \multicolumn{9}{|l|}{ Pemberian ASI } \\
\hline Eksklusif & & & & & & & \multirow{3}{*}{0.000} & \multirow{3}{*}{5.902} \\
\hline Kurang Baik & 21 & 70.0 & 17 & 28.3 & 21 & 70.0 & & \\
\hline Baik & 9 & 30.0 & 43 & 71.7 & 9 & 30.0 & & \\
\hline \multicolumn{9}{|l|}{ Status Gizi } \\
\hline Tidak Normal & 14 & 46.7 & 7 & 11.7 & 14 & 46.7 & \multirow[t]{2}{*}{0.001} & \multirow[t]{2}{*}{6.625} \\
\hline Normal & 16 & 53.3 & 53 & 88.3 & 16 & 53.3 & & \\
\hline \multicolumn{9}{|l|}{ Kualitas Jamban } \\
\hline Tidak Memenuhi & 21 & 70.0 & 19 & 31.7 & 21 & 70.0 & \multirow{3}{*}{0.001} & \multirow[t]{3}{*}{5.035} \\
\hline Syarat & 9 & 30.0 & 41 & 68.3 & 9 & 30.0 & & \\
\hline \multirow{2}{*}{\multicolumn{9}{|c|}{$\begin{array}{l}\text { Memenuhi Syarat } \\
\text { Sumber air bersih }\end{array}$}} \\
\hline Sumber air bersih & & & & & & & & \\
\hline Tidak memenuhi syarat & 12 & 40.0 & 8 & 13.3 & 20 & 22.2 & \multirow{2}{*}{0.009} & \multirow[t]{2}{*}{4.333} \\
\hline Memenuhi syarat & 18 & 60.0 & 52 & 86.7 & 70 & 77.8 & & \\
\hline
\end{tabular}

